\title{
Problems of Water Deficit in the World and Azerbaijan and Scientific Practical Solution
}

\author{
Aliev ZH* \\ Department of Soil Science and Agro chemistry, National Academy of Sciences of Azerbaijan, Azerbaijan
}

*Corresponding author: Aliev ZH, Institute of Erosion and Irrigation of Azerbaijan National Academy of Sciences, Azerbaijan.
Received Date: June 23, 2020

Published Date: July 09, 2020

\begin{abstract}
The rapid growth in world population and limitation of soil and water resources have caused major problem for human nutrition security in the world. only $3 \%$ of water resources are fresh water. Accoding to the FAO report, if in the any country Amount of fresh water is less than $1700 \mathrm{~m}^{3}$ per capita, this country is faced to serous water shortage. At the present, in the 22 countries share of fresh water per capita is less than $100 \mathrm{~m} 3 \mathrm{and}$ in the 18 countries is more than $2000 \mathrm{~m}^{3}$. Therefore, Azerbaijan is one of the countries which have faced serous water shortage.
\end{abstract}

Keyword: Water and soil resources; Shortage; FOOD nutrition; Kg/m³

\section{A Glance to Water and Soil Resources in the World}

The rapid growth in world population and limitation of soil and water resources have caused major problem for human nutrition security. Some $40 \%$ of the world's land surface is used for the purposes of keeping all 7 billion of us fed. And the vast majority of that land - about $30 \%$ of the word's total ice-free surface - is used not to raise agriculture productions. Water is the driving force of all nature.

The annual renewable water of this country is 7-9 milliard $\mathrm{m}^{3}$. Increasing population on the one hand and limitation of water and soil resources on the other hand is major challenge for Azerbaijan. More than $60 \%$ or 5.4 milliard m3water resources are used by agriculture sector. Refer to Government program in the 2007, the annual agricultural production has been $6521788 \mathrm{MT}$. In fact $0.73 \mathrm{~kg}$ agricultural production is produced per one cubic meter water. For providing food security, it must be increased to $1 \mathrm{Kg} / \mathrm{m}^{3}$ in 2025 and $1.5 \mathrm{Kg} / \mathrm{m}^{3}$ in 2050 by using scientific method such as modern irrigation systems and agro-technology.
Unfortunately for our planet, supplies are now running dry - at an alarming rate. According to the FAO report, if in the any country Amount of fresh water is less than $1700 \mathrm{~m}^{3}$ per capita, this country is faced to serous water shortage. At the present, in the 22 countries share of fresh water per capita is less than $100 \mathrm{~m} 3$ and in the 18 countries is more than $2000 \mathrm{~m} 3$. According to current projections of POPULATION growth, the world population of humans will continue to grow until at least 2050, with the estimated population, based on current growth trends, to reach 9 billion in 2040 [1,2] and some predictions putting the population in 2050 as high as 11 billion [3]. World population passed the 7 billion mark on October 31, 2011[1]. The amount of precipitation falling on land is almost $110000 \mathrm{~km}^{3}$ per year. About 56 percent of this amount is evapo transpired by forests and natural landscapes and 5 percent by rain fed agriculture. The remaining 39 percent or $43000 \mathrm{~km}^{3}$ per year is converted to surface runoff (feeding rivers and lakes) and groundwater (feeding aquifers). These are called renewable freshwater resources. At global level, the withdrawal ratios are 69 percent agricultural, 
12 percent municipal and 19 percent industrial. These numbers, however, are biased strongly by the few countries which have very high-water withdrawals. Averaging the ratios of each individual country, we find that "for any given country" these ratios are 59, 23 and 18 percent respectively [4] (Figure 1).

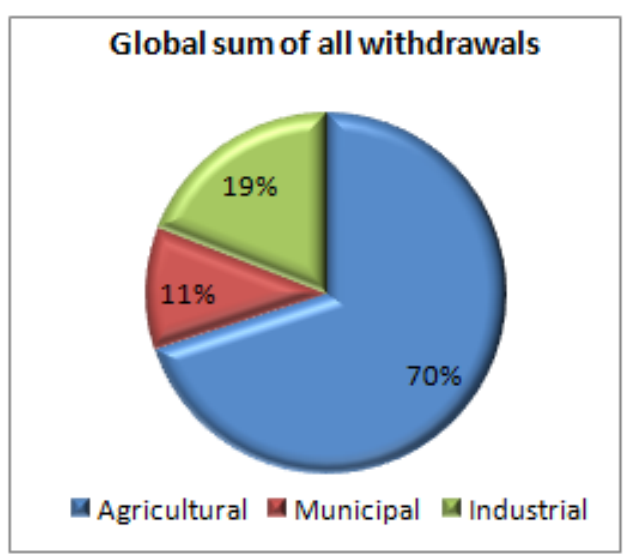

Figure 1: @ FAO Food and Agriculture Organization of the United Nations - Global Sum of all withdrawals.

Today, 2.5 billion people lack access to improved sanitation, of which 1 billion practice open defecation. Poor sanitation impacts health, education, the environment, and industries such as tourism. At least 700 million people lack access to safe drinking water. Poor sanitation, water, and hygiene lead to about 675,000 premature deaths annually, and the lack of access to safe water results in up to 7 percent of GDP in equivalent economic losses in some countries every year. Water challenges cut across economic sectors. The global population is growing fast and estimates show that with current practices, the world will face a 40 percent shortfall between forecasted demand and available supply of water by 2030. Today, 70 percent of global water withdrawals are for agriculture. Feeding 9 billion people by 2050 , will require a 60 percent increase in agricultural production and a 15 percent increase in water withdrawals. More than half of the world's population now lives in urban areas. And the number is growing fast. By 2025, about 1.8 billion people will be living in regions or countries with absolute water scarcity.

\section{A Glance to Water and Soil Resources in the Republic Azerbaijan}

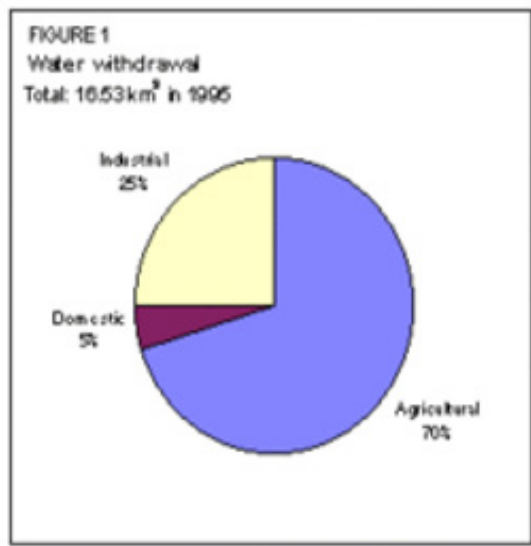

Figure 2:

Table1: The growth of population Republic of Azerbaijan from 2015 to2050.

\begin{tabular}{|c|c|}
\hline Year & Population (1000) \\
\hline 2015 & 9613 \\
\hline 2020 & 10030 \\
\hline 2025 & 10309 \\
\hline 2030 & 10474 \\
\hline
\end{tabular}




\begin{tabular}{|l|l|}
\hline 2035 & 10570 \\
\hline 2040 & 10614 \\
\hline 2045 & 10590 \\
\hline 2050 & 10492 \\
\hline
\end{tabular}

Azerbaijan, a mountainous country bordered by the Caspian Sea. The agricultural area is 4756,5 thousand hectares, accounts for 55 percent of the country's total area and contributes about 13 percent to the country's GDP. Azerbaijan is one of the countries which have faced serous water shortage. The total inflow into Azerbaijan is thus estimated at $20.980 \mathrm{~km}^{3}$ /year. e. Increasing population on one hand and limitation of water and soil resources on other hand is major challenge for Azerbaijan. The growth of population Republic of Azerbaijan from 2015 to 2050 has been showed in table1. The internally generated surface water resources are estimated at $5.955 \mathrm{~km}^{3} /$ year. The total renewable surface water resources (RSWR), including incoming and bordering flows, are estimated at $28.115 \mathrm{~km} 3 /$ year. In 1995, the total water withdrawal for agricultural, domestic and industrial purposes was $16.53 \mathrm{~km}^{3}$, of which over $70 \%$ was used for agricultural uses and almost $25 \%$ for industrial purposes (Figure 1) (Table 1).

Soil salinization and sodication have been identified as major processes of land degradation and loss of agricultural production. It should be noted that $60 \%$ of the territory of the country is mountainous and natural and anthropogenic factors, causes all kinds of erosion processes in the lands [5].

$\Phi$ The results of researches have showed that the processes of all kinds of erosion are outspread in our country widely. Currently, more than $41.8 \%$ arable land of country has been eroded by various degrees of erosions and in some region, it is reached to $70-85 \%$ $[5,6]$. Irrigation erosion is the biggest factor of mentioned challenges. Irrigation in farming, gardening and livestock lead to the erosion of land, any time people are not paying attention to soil protection during agricultural activities [2].

Table 2:

\begin{tabular}{|c|c|}
\hline Year & Population (1000) \\
\hline 2015 & 9613 \\
\hline 2020 & 10030 \\
\hline 2025 & 10309 \\
\hline 2030 & 10474 \\
\hline 2035 & 10570 \\
\hline 2040 & 10614 \\
\hline 2045 & 10590 \\
\hline 2050 & 10492 \\
\hline
\end{tabular}

According to World Bank statistics, the population of Azerbaijan was marked 8581300 person in 2017(9) and refer to Azerbaijan governmental program the annual Water reserves was 7-9m3and annual agriculture production amount was 6521788 ton 7.There-
Our Country has been faced acute water shortage. The Water reserves of this country is 32,5 billion cubic meter. In dry years, this amount is reduced up to 23,16 billion $\mathrm{m}^{3}$. Only $30 \%$ of this amount of water resources are used inside country and the remaining $70 \%$ it the trilled to neighboring countries territory [4].

The result of research showed that the modern irrigation systems are used in $4 \%$ of arable land and remaining $96 \%$ are irrigated by traditional method like as flooding and furrow manner. Therefore, in the arable land, the underground water level rises gradate. Even in the some areas more than 100thousand hectares, underground water level has been reached to surface of suitable arable land and caused salinization problems $[2,4]$. The results of study show that, the Water reserves in Georgia, Armenia and Azerbaijan are about 70, 25 and 10 billion $\mathrm{m}^{3}$ respectively. Otherwise the annual Water reserves per capita 11000, 3000 and $1500 \mathrm{~m} 3$ respectively in these countries. According to the result of studies, in 2020, the annual Water reserves per capita in Azerbaijan reduced 2 times compare to Georgia and times to Armenia [4].

\section{Result}

Water challenges cut across economic sectors. The global population is growing fast and estimates show that with current practices, the world will face a 40 percent shortfall between forecasted demand and available supply of water by 2030 . Today, 70 percent of global water withdrawals are for agriculture. Feeding 9 billion people by 2050 will require a 60 percent increase in agricultural production and a 15 percent increase in water withdrawals. According to UN prognoses reports the Azerbaijan population rise from 9613 person in 201510492 person to in 2050 as the following (table 2). fore the annual Water reserves per capita 815-1049 cub meter and withdrawals for agriculture were 5.4 billion cub meter. On otherwise, for 1 cubic meter water, $0.7 \mathrm{~kg}$ Agriculture production was produced. In Azerbaijan governmental program for agriculture pro- 
duction in 2015, the share of per capita of agriculture product has been prognoses 11.2 ton per year. At present, Changeable climate concept, the population growing, indicate that supplying human feed will be impossible by mentioned conditions. For providing food security, it must be increased to $1 \mathrm{Kg} / \mathrm{m}^{3}$ in 2025 and $1.5 \mathrm{Kg}$ / $\mathrm{m}^{3}$ in 2050 by using scientific method such as modern irrigation systems and agro-technology.

\section{Recommendation}

1. Water is at the center of economic and social development: it is vital to maintain health, grow food, generate energy, manage the environment, and create jobs. Refer to mentioned conditions in the many countries, the efficiency of agriculture products must be calculated by consumption water for one-kilogram product instead of ton/ha.

2. Priority of Farm management and Utilization modern irrigation systems on farm and erosion protection on the annual Azerbaijan governmental program.

3. Creation Education and Extension on Agricultural ministry for Practical Instruction of farmer and extension of modern agro-technology throughout country.

\section{Acknowledgment}

None.

\section{Conflicts of Interest}

No conflicts of interest.

\section{References}

1. Aliev BH, Aliev ZH and others (1999) Techniques and technology few intensive irrigations in condition of the mountain region Azerbaijan. Elm, Baku, p. 220.

2. Aliev BH, Aliev ZH (2007) The premises about the most important problem of the agriculture in provision water resource mountain and foothill regions Azerbaijan J. AAS, Baku, p.179-182.

3. Aliev BH, Aliev ZH (1999) The premises of the decision of the problem's moisture provides agriculture cultures production in mountain and foothill region Azerbaijan. The works SRI Erosions and Irrigations. Baku, p.125-129.

4. Guseynov NM (1969) Ways to improve the efficiency of use of irrigated land, improved technologies and methods for irrigation of agricultural crops in Azerbaijan. Report on the degree of competition. CcD on the basis of works, Baku, 214-230.

5. International Center $\mathrm{C} / \mathrm{X}$ Research in the dry in the Dry Areas (ICARDA) Irrigation regime and monitoring equipment. Edited U Umarova and A Karimov. Taraz AQUA p. 128.

6. Mountain Forests Ecology, Anthropogenic Degradation and Ways to Improve-sentyabr 2016 №8. 